
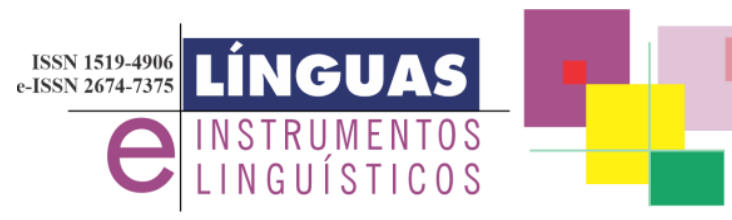

DOI: $10.20396 /$ lil.v24i47.8666687

\title{
A cidade dos 2010 na Análise de Discurso Brasileira
}

\section{The city of the 2010's at the Brazilian Discourse Analysis}

\section{Mariana Garcia de Castro Alves* UNICAMP}

Resumo: $O$ espaço urbano na análise de discurso brasileira, que tomamos pelo nome Eni Orlandi, é decisivo para a compreensão dos processos de significação na contemporaneidade. Pela proximidade e especificidade histórica, a cidade da década de 2010, cujas movimentações continuam a irradiar interpretações das mais diversas, permanece demandando sentidos. No rastreamento de uma teoria discursiva da cidade, o artigo seleciona ensaios de Orlandi sobre o urbano produzidos nesses anos. Ao realizar análise fatorial com o auxílio de ferramentas de textometria, o trabalho aponta, como gesto de interpretação, um modo de ler essa produção, voltada ao "real da cidade" em seus fluxos, no compasso do farol ao qual se assujeita o malabares e no ritmo do passinho da garotada da periferia a animar os pancadões.

Palavras-chave: Discurso, Cidade, Textometria, História das Ideias Discursivas.

Abstract: Urban space in the brazilian analysis of discourse, which we take by the name Eni Orlandi, is decisive for the understanding of the processes of signification in contemporary times. Due to its proximity and historical specificity, the city of the 2010's, whose movements continue to radiate the most diverse interpretations, remains demanding meanings. In tracking a discursive theory of the city, the 
article selects Orlandi's essays about the urban space produced in those years. When carrying out factorial analysis with textometry tools, the work points out, as a gesture of interpretation, a way of reading this production, focused on the "real of the city" in its flows, in the compass of the traffic light to which the jugglers are subjected and in the rhythm of the passinho of the youth of the periphery to animate the beats.

Keywords: Discourse, City, Textometry, History of Discursive Ideas.

O presente artigo busca compreender os movimentos teóricos da análise de discurso brasileira nos anos 2010 de modo a identificar como esse espaço de significação em tal configuração põe questões a esse campo de estudos.

Ao enunciar a existência de uma análise de discurso brasileira, filiando-nos a ela, e ao remetê-la a um nome, Eni Puccinelli Orlandi, partimos da consideração de que seu percurso teórico desde os anos 1970 estampa transformações históricas importantes e indissociáveis de suas contribuições para a análise de discurso criada na França nos anos 1960. Entre os anos de fundação e os de "des-transformação" brasileira da disciplina (ALVES, 2020), o urbano passa a ocupar um lugar decisivo para os movimentos do capital, que faveliza, bunkeriza etc. Esse lugar afeta a teoria, que deixa o chão de fábrica, hoje habitada por robôs, e os discursos de organizações de classe e políticas tradicionais para a compreensão dos sujeitos na cidade.

Embora o discurso urbano apareça tangencialmente em análises desde, pelo menos, os anos 1980 (ORLANDI, GUIMARÃES e TARALLO, 1989) e seja objeto de elaborações importantes nos 1990, o ápice de seu tratamento por Eni Orlandi situa-se no novo século, com Cidade dos Sentidos (2004). Nessa obra, a problemática urbana é sistematizada com noções como, por exemplo, a de "quantidade" - o excesso do urbano que faz que a metaforização dos sentidos seja prejudicada, gerando violência - e a de "indistinção" - que já havia aparecido em As formas do silêncio (1992) e é trabalhada como efeito da mistura linguística do italiano com o português em Interpretação (1996) - que ganha peso, em 2004, como efeito que indistingue o socius (nossos iguais) do hostis (inimigos) e indistingue o corpo do sujeito do corpo da cidade, o espaço público do privado, entre outros pares 
citadinos. Após isso, em 2010, com o texto Formas de individuação do sujeito feminino e sociedade contemporânea: o caso da delinquência (2010), Orlandi dedica-se às diferenças entre formações discursivas vistas como homogêneas pelas políticas públicas, destacando a segregação como um modo de existência de sujeitos sobre o qual o consenso não é capaz de operar de forma única. Assim, toca em contradições relativas ao tipo de neoliberalismo inclusivo que, sob um discurso de pacto nacional, inclui parcelas importantes em um sistema, mas as inclui em um sistema de grande desigualdade e selvageria. No esgarçamento social, a análise aborda contradições que, vistas retrospectivamente, desaguam nas manifestações de 2013, cujos efeitos ainda se fazem presentes em um estado de crise permanente.

Embora se trate de um período de conturbação social intensa que determina a política ulterior do país, Orlandi não se inscreve no gênero ensaístico dedicado àquelas "Jornadas de Junho". Em vez disso, sobre a cidade, observará os Fluxos que a constituem, seus ritmos, seus sujeitos na intimidade de suas relações, nos vínculos que estabelecem para sua sobrevivência material e simbólica. Mais à maneira de uma intérprete de um Brasil no qual os laços da intimidade contam mais que os rituais do Estado que aqui sempre foram de falha, a despeito da vida íntima não ser nem bastante coesa nem bastante disciplinada (HOLANDA, [1936] 1995, p. 151), Orlandi construirá dispositivos analíticos a partir dos malabares do semáforo, do grupo de jovens que saem de suas casas para festas de funk nas ruas para dançar, do pichador... Dos movimentos de um "real da cidade". Como se quisesse compreender suas necessidades sem veleidades e seus sentidos entre dois mundos: "um definitivamente morto e outro que luta por vir à luz" (idem, p. 180).

\section{Anos de indistinção}

Os anos 2010 nas ruas brasileiras foram marcados por contrastes e indistinções. Se, por um lado, as populações urbanas viam-se, de certo modo, mais inseridas no mercado - a taxa de formalização passara de $50,5 \%$ em 2000 a 58,6\% em 2010 (IBGE, 2014) -, por outro, já na primeira metade da década, a euforia dava espaço à insatisfação.

Em 2013, o enunciado "não é só por 20 centavos" que marcou o maior ciclo de manifestações na história do Brasil, expressava pelo 
"não" uma recusa. Porém, ao mesmo tempo, se não era por vinte centavos, poderia ser por qualquer coisa. As Jornadas de Junho, esse movimento multifacetado ideologicamente, em fluxos de indistinção, gerou, assim, inúmeras interpretações. Para uns, 2013 significou a ingratidão dos revoltosos e a falta de consciência de classe de um povo que passava a trair seus próprios interesses. Para outros, o esgotamento da capacidade petista de mediar as tensões sociais. De fato, ficava patente que aquele "neoliberalismo inclusivo" da década anterior e implantada governos progressistas não abrira caminho para o apaziguamento social. Parecia, pelo contrário, que a gestão da crise capitalista com mais neoliberalismo, em sua versão inclusiva, tornavase um torniquete a dar ainda maior força às insatisfações (FELDMANN, 2020). Por exemplo, as gerações que, pela primeira vez, tiveram acesso à educação superior - que havia sido expandida principalmente pelo crédito privado - não eram absorvidas pelo mercado de trabalho de uma economia periférica que, no caso, já havia perdido a quarta revolução industrial e não solucionava seus problemas estruturais nem gerava emprego. Assim, conforme análise de Scherer et al., 2013 constituiu-se como uma recusa do consenso em meio a desigualdades (SCHERER et al., 2014, p. 24).

Inegavelmente, a cidade é o palco onde se dão tais expressões de insatisfação, embora as manifestações tenham sido combinadas pela internet e julgamentos políticos tenham sido assistidos pela TV como se fossem novelas. Em cinquenta anos, desde 1964, era a primeira vez que a direita passava a se manifestar recorrentemente nas ruas, cada vez mais ocupadas por moradores sem teto. Entre a deposição de Dilma Rousseff em 2016, a prisão de Lula e a eleição de Bolsonaro em 2018, uma recessão econômica a partir de $2015^{1}$ aumenta a crise social. Dessa maneira, já no fim da década, o número de moradores de rua da cidade de São Paulo cresce pelo menos 60\% em 2019 em comparação com 2015, passando de 15 mil para 24 mil e 300 pessoas, conforme censo da prefeitura, contestado por representantes de movimentos de moradia que apontavam que o número de pessoas em situação de rua chegava a 32 mil (LIN, 2020).

Diante desse cenário de agravamento da crise, nota-se a dissolução de laços e, com o acirramento da concorrência, retorna o estado natural hobbesiano de guerra de todos contra todos. Eni Orlandi - que pusera a cidade em foco ao realizar uma "des-transformação" da análise de 
discurso pechetiana (ALVES, 2020) - observa tais fenômenos e em vez de tomar a forma de motim como significativa para a análise, tenta entender a cidade pelo questionamento do que junta as pessoas em processos de "latência". Em meio à indistinção manifesta nas ruas, ao buscar a profundidade dos processos sociais de sentido, volta-se aos fluxos na cidade.

Se sou tentada a embarcar nestas características do "processo de reinvenção da política", e pelos modos de construção pelas redes, no entanto não me convencem, pelo que compreendo do que podem as redes, e sou muito avessa à ilusão da informação como móvel do político, do mesmo modo que sei que a mídia não funciona pela comunicação, embora tenha enorme força na produção de um imaginário social de informação como "revelação" da realidade.

Porém, algo aí me interessa: é o que chamam latência (e visibilidade), na criação de novas formas de juntarem-se sujeitos, improvisando relações sociais à margem, na periferia. E a ocupação dos espaços públicos (ORLANDI, [2015] 2017, p. 143).

Assim, os objetos aos quais se dedica durante os anos 2010 constroem-se a partir de um gesto epistemológico voltado não aos movimentos sociais, mas, de modo mais profundo, aos movimentos na sociedade. Diferentes dos primeiros, os segundos referem-se aos fluxos visíveis do que chama de um "real das relações sociais". Partindo dos dispositivos teóricos da Análise do Discurso (AD), aponta que a constituição do sujeito não se dá só enquanto movimento social, contrariamente à posição de Alain Touraine, citado pela autora, que afirma o ator/sujeito só como movimento social. Para Orlandi, "a noção de indivíduo já é uma noção político-social” ([2015] 2017, p. 142), o que se traduz teoricamente pelo que já vinha afirmando serem os modos de individuação do sujeito pelo Estado. São tais modos, relativos à individuação, que permitem as falhas, estas que determinam a constituição dos sujeitos pela ideologia. Dessa maneira, os malabares no semáforo, por exemplo, "lateja os sentidos de ocupação do espaço 
social" (2017, p. 126). Portanto, a "latência" - palavra que toma de Touraine mas é por ela deslocada - torna-se um modo de reconhecer, por sua visibilidade, "o real do que chamamos relações sociais" (ORLANDI, [2015] 2017, p. 150 e 2017, p. 126).

A não resolução das contradições estruturais brasileiras, ao acelerar a máquina e sua lógica individualista, aprofunda as fissuras sociais. A segregação como fato de sentido, a constituir seus efeitos em uma sociedade $^{2}$ em que as pessoas falam e silenciam de mundos diferentes ("Se observarmos de nosso mundo, é estranhíssimo [...]" (ORLANDI, 2010, p. 35)) dadas tais fissuras, determina que a indagação sobre os sentidos seja em si contraditória: como se dão os vínculos onde/quando os vínculos estão cada vez mais desfeitos?

\section{Dispositivos analíticos}

Selecionamos quatro textos de Orlandi para compreender como a análise de discurso brasileira faz essa questão a partir de 2010. São eles:

- Formas de individuação do sujeito feminino e sociedade contemporânea: O caso da delinquência (2010);

- A casa e a rua: uma relação política e social (2012);

- Dancinha: da rarefação do espaço social para as ruas. Ou uma rua chamada Terra Brasileira, na zona leste de São Paulo ([2015] 2017);

- Malabares - a relação entre espaços: o factual e a tópica cívica (2017).

Submetemos tais textos a uma plataforma francesa de "textometria", de acesso aberto, chamada TXM, que nos dá ferramentas de frequência, coocorrência e uma "nuvem" de formas gráficas (AFC - Análise Fatorial de Correspondências) (Fig. 1).

$\mathrm{Se}$, por um lado, tais ferramentas orientam a leitura do arquivo, fazendo que sejamos apenas extensão da técnica, por outro lado, invocam uma leitura não-subjetiva, cara à história da $\mathrm{AD}$ em sua luta contra a circularidade da interpretação, isto é, ao fato de, muitas vezes, o analista encontrar apenas o que já queria encontrar. Embora nos deixemos embalar pelas facilidades técnicas de averiguar, facilmente, 
um ou outro termo no corpus e ter dele uma imagem de relações entre as palavras, em certo momento o resultado opaco da máquina nos oprime. Tal opressão é paradoxal pois, não obstante se constituir como resultado de nosso corte, faz-nos seguir um caminho por ela desenhado, ideologicamente alinhado aos critérios científicos instrumentais de redução do imaginário. A despeito dessa redução, mas também por causa dela, somos levados a ultrapassar as evidências subjetivas de leitura, no processo de interpretação do arquivo.

Tal "nuvem de palavras" (AFC) construída pela máquina a partir da distribuição das formas gráficas (quaisquer formas separadas por espaços) entre si nos textos evoca, na linguística tal como compreendida no século $\mathrm{XX}^{3}$, o distribucionalismo de Zellig Harris, que é um dos empréstimos feitos pela $\mathrm{AD}$ em sua constituição. Ao explicitar tal metodologia, podemos, assim como Pêcheux recomenda ${ }^{4}$, criticá-la. A crítica, do nosso ponto de vista, seria imprescindível caso se tomasse os resultados distribucionais da leitura automática como transparentes. $\mathrm{Ou}$ seja, uma leitura que tomasse os textos escolhidos como ponto de partida e de chegada sem concebê-los como abertos às condições de produção (ORLANDI, GUIMARÃES, [1988] 2008) seria o alvo para onde deveríamos apontar nossas flechas. Importante ressaltar, de imediato, que, portanto, a crítica à técnica não deriva aqui de um julgamento de que a máquina não consiga lidar com as falhas das línguas naturais, nem de que não represente "a verdade" dos textos. A crítica deve, sobretudo, mostrar pela análise como o resultado da máquina faz-se espesso, opaco, passível de múltiplas leituras, pela historicidade e provisoriedade do arquivo.

Feita essa prevenção e breve explicitação de nosso procedimento, passemos à análise.

\section{Análise}






Fig. 1: Plano fatorial de análise de correspondências sobre a partição "anos".

Após digitalizar e transferir nosso corpus ao programa, geramos a AFC cujo resultado se vê na Fig. 1. O que se destaca inicialmente é um encavalamento de dois textos, A casa e a rua...(2012) e Dancinha... ([2015] 2017), no primeiro quadrante, onde aparece o nó cidade. Junto a esse nó, também puxados por dancinha, estão as formas casa, rua, público, urbano, movimento e movimentos. São textos escritos em anos diferentes, mas que se sobrepõem na AFC.

Todo o lado esquerdo do plano cartesiano fica com o texto Formas de individuação... (2010). No segundo quadrante, os nós político, capitalista e favela estão às margens. Favela, em direção ao terceiro quadrante, segue em aproximação a Falcões, discurso e mundo.

No quarto quadrante, puxados por malabares e semáforo, estão os nós tópica, cívica, lugares, memória e noção. Nessa região estão os nós que mais aparecem no texto Malabares... (2017).

A princípio, trata-se de divisões temáticas sobre um período relativamente curto de tempo, sincrônico, que podem, entretanto, dizer de movimentações teóricas vistas em diacronia.

Nosso gesto de interpretação é o de mobilizar alguns nós que estão à margem e estabelecer "choques sinonímicos" - a expressão é de Milner (2006, p. 41-48) - com o objetivo de tentar encontrar maneiras com as quais o arquivo faz funcionar as contradições (ALVES, 2020, 
p. 78-79). Por choque sinonímico entendemos um momento em que nós que estão posicionados em polos opostos podem se tocar em um ponto de contradição. Esse ponto, de sinonímia porque sobre uma mesma questão, daria a ver um momento de contradição em que os sentidos do arquivo podem ser movimentados pela leitura.

A partir dessa nuvem gerada pelo programa, realizaremos um choque entre cidade, no primeiro quadrante, com seu "oposto" discurso, no terceiro quadrante; e entre político, no segundo quadrante, com seu "oposto" memória, no quarto quadrante. Não consideramos esses nós em sua oposição contrastiva, pois não se trata de estabelecer o "a cada um [a cada texto] o seu discurso" (COURTINE, [1982] 2016, p. 18). Preferimos antes fazer a máquina nos colocar questões (HENRY, 2010, p. 38) relativas às contradições que movimentam esse arquivo. $\mathrm{O}$ intuito é refletir sobre como esses movimentos, dados pela leitura automática, podem suscitar um gesto de interpretação. Ademais, e retomando, de que modo esse arquivo aponta questões concernentes à reflexão sobre vínculos em época de rupturas.

\subsection{A memória e o político}

Iniciemos com a reflexão sobre a relação entre o nó político $\left(2^{\circ}\right.$ quadrante) e o nó memória (4º quadrante).

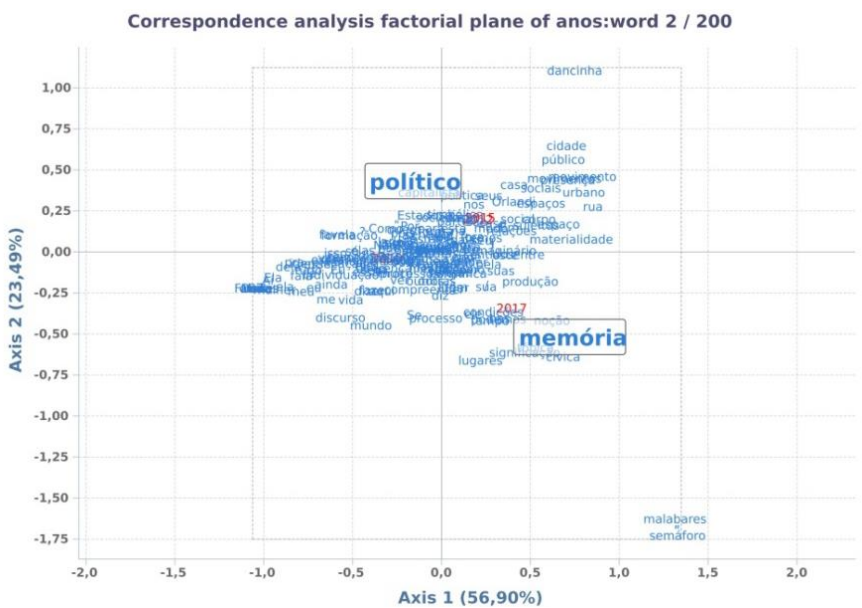

Fig. 2: Nó político, no $2^{\circ}$ quadrante, e nó memória, $4^{\circ}$ quadrante. 
"No momento em que a palavra ideologia desaparece, a palavra memória se instaura", constatou certa vez Régine Robin em entrevista (ROBIN, 2019, p.153) ao exemplificar a necessidade, a partir de determinada época, de ultrapassar as simples relações de classe. Ideologia tinha seus efeitos em uma sociedade em que o lugar ocupado na produção era decisivo na tensão entre a burguesia e a classe trabalhadora, em economias pujantes garantidas pelo Estado, nos países europeus do pós-guerra. Quando essa era de ouro se esgota, nos anos 1970, com a chamada terceira revolução técnico-científica, estagnação, financeirização, flexibilização das relações de trabalho e aumento da informalidade, a ideologia dá lugar à memória, conforme constata Robin.

Se isso ocorre nos estudos discursivos de modo geral, no que diz respeito à $\mathrm{AD}$ brasileira, ideologia convive com memória de modo particular. Tal convívio, que é motivo de estranhamento no exterior, no Brasil não causa monta. Em um país que nunca chegou a ser uma sociedade salarial, diferentemente da Europa do pós-guerra, as relações nunca se deram apenas pelas características clássicas de mercado. Por exemplo, as relações na periferia do capitalismo não se dão apenas pela impessoalidade das trocas, mas por uma complexa série de expedientes como o favor do qual dependem os agregados, tão bem caricaturados por Machado de Assis (SCHWARZ, [1977] 2012, p. 16). Assim, no Brasil, ideologia está longe de ser apenas um conceito que era funcional para um arranjo entre trabalho e capital - aquele em que os trabalhadores organizados em sindicatos com suas reivindicações obrigavam a burguesia a abrir mão de parte de seus lucros - que, a partir dos anos 1970, desfaz-se porque esse próprio arranjo nunca se deu localmente. O próprio subdesenvolvimento como uma exceção dentro do sistema ${ }^{5}$ explica, de certo modo, uma das particularidades da teoria brasileira do discurso. Entende-se, assim, que, em nosso corpus, ideologia ocorra 30 vezes enquanto memória também apareça em alta frequência, em 36 oportunidades.

Explicada sua ocorrência como não excludente à noção de ideologia, esta que constitui o sujeito com relação aos sentidos, à história e às condições em que ele vive, memória tem um papel relevante quando o assunto é cidade. 
Com o foco na relação entre o nó memória e o nó político, vejamos como esses termos se distribuem pelo arquivo, ou, em termos harrisianos, em que "ambientes"6 aparecem.

Em relação ao esquecimento, Orlandi em Formas de individuação... (2010) refere-se a Nicole Loraux, que escreve "La cité divisée : l'oubli dans la mémoire d'Athènes" (1997). A reflexão de Orlandi é feita partindo da delinquência como sendo "sintoma da necessidade social que é própria do sujeito enquanto ser simbólico." (ORLANDI, 2010, p. 12). Loraux mostra que em Atenas lembrar de esquecer determinado fato era um modo de manter a comunidade coesa. Na guerra, prossegue a leitura da Orlandi, escolhiam-se trinta pessoas, julgadas culpadas, e dava-se a elas o direito de continuar a "seguir a vida". A questão, então, seria como a memória e o esquecimento trabalhariam na cidade hoje com relação aos "culpados", aos "banidos". Para manter o consenso, o que o funcionamento do Estado obrigaria que fosse esquecido?

Em 2014, o número de presos no Brasil havia superado 570 mil pessoas, tornando o País o terceiro maior em população carcerária do mundo, apenas atrás de Estados Unidos e China, de acordo com dados do Conselho Nacional de Justiça (CNJ). Nos até então doze anos de governos Lula e Dilma, o aumento carcerário havia sido de mais de $620 \%$, enquanto o populacional tinha sido de cerca de $30 \%{ }^{7}$. Pode-se pensar que tal política de segurança pública, baseada apenas em repressão e no aumento de vagas em presídios, trabalha na redução dos diversos sentidos de delinquência, canalizando-os ao de banimento e eliminação social. Uma política desse tipo, portanto, atribui sentidos únicos ao crime e à delinquência, fazendo esquecer outros sentidos, como os por exemplo de Dona Leda, chefe do tráfico analisada em Formas de individuação... (2010).

O nome dado por Orlandi ao que "deveria" ser esquecido é "o político": "Para formar o consenso, na relação entre o jurídico e o administrativo, que foi nosso objeto coletivo de pesquisa, o que é esquecido seria justamente o político?” (ORLANDI, 2010, p. 13) Apreende-se, assim, que a política apague o político, este sendo o nome que a autora significa como "a divisão de sentidos" (ORLANDI, 1996, p. 21).

Nessas condições, a integração social tem como um de seus componentes a criação de uma necessidade de muros, de "segurança", em outras palavras, de ódio aos de baixo. Segundo Michelle Alexander, 
em resposta a quem afirma que o encarceramento cresce porque com a crise econômica o crime aumenta, "as origens desse sistema tem muito menos a ver com crimes ou com índices de criminalidade do que com nossa história racial e com nossa política racial - a política do medo, da divisão, do bode expiatório e do controle" (ALEXANDER, prefácio a edições estrangeiras, 2018). ${ }^{8}$ Assim, o crime em si não seria algo claramente determinável e as próprias infrações só seriam como tais consideradas para determinados sujeitos e não para outros. Em termos de Orlandi, essa divisão se constituiria no apagamento do sentido de delinquência como sendo, para os segregados, o "a-mais necessário para a sobrevivência" (ORLANDI, 2010, p. 14). Independentemente dos governos, em um sistema econômico incapaz de integrar a todos, de segregação - o que nota Orlandi (idem, p. 13) ao se referir a Schaller (2001) quando este afirma o fim da verticalidade das relações, isto é, o fim da perspectiva de ascensão - o aumento da população carcerária não tem a ver apenas com o crescimento da criminalidade nas comunidades empobrecidas, mas com um modo de lidar com uma população sem perspectiva de integração pelo trabalho, em uma fase em que o capitalismo não mais o gera como outrora, incentivando a concorrência selvagem.

Notamos que memória, embora se instale no quadrante do texto Malabares... (2017), percorre todos os outros textos, movimentando sentidos desse recorte. Todavia, é no ensaio sobre esses sujeitos na cidade que manifesta seu funcionamento no movimento dos sentidos em relação a outros nós vizinhos como aos referidos à noção de tópica cívica, por exemplo. Se um sentido se relaciona ao esquecimento dos sentidos de delinquência, outra noção ligada à de memória que se estabelecerá durante os anos 2010 é a da "narratividade", que já aparecera no texto "Tralhas e Troços: o Flagrante Urbano" de Cidade dos Sentidos (2004). Narratividade é abordada como a:

maneira pela qual uma memória se diz em processos identitários, apoiados em modos de individuação do sujeito, afirmando/vinculando seu pertencimento a espaços de interpretação determinados, consoantes a específicas práticas discursivas. (ORLANDI, 2017, p.115) 
Ao ilustrar a noção com uma imagem, Orlandi diz:

De dentro de uma sala, ao abrir a janela e ao olhar o céu, é o espaço da janela que você vê. Ou seja, é o enquadramento de espaço feito pela narratividade, funcionamento de memória que o malabares se conta' ${ }^{9}$, que recorta, dá a perspectiva (...). (ORLANDI, 2017, p. 116)

O sujeito vincularia "seu pertencimento a espaços de interpretação determinados" por um enquadramento espacial dado por essa "memória (que) se diz".

Importante observar que essa circunscrição de espaço, feita pelo sujeito ao se contar, se dá "dentro da narratividade mais ampla que o está inscrevendo num processo de significação, determinando-se em uma tópica cívica”. Dá-se a entender que a narratividade, a memória se dizendo, está inscrita em uma situação em sentido mais amplo, no que chama tópica cívica - diferente do espaço empírico, por comportar o simbólico e o imaginário. Portanto, os malabares constituiram-se não pela "construção discursiva referencial", isto é, pelo carro que quase o atropela ("tu") ou pelo guarda que o ameaça ("ele", o Estado), em distinções cristalinas, mas na opacidade. Os sentidos, que sempre são sujeitos a equívoco, o são especialmente quando se fala em tópica cívica por sua relação com a narratividade, aos modos múltiplos, diversos, errantes de como a "memória se diz":

Correm, paralelamente, outras determinações que constituem a tópica cívica, nas ligações estabelecidas, por ele, com o movimento da sociedade que significam pelo deslize, em outras versões, narrativamente, no que sua memória se diz; o semáforo, nicho de sobrevivência, é um ponto de fuga dos sentidos: sua casa. Os sentidos não são claros e distintos. São opacos e sujeitos a equívoco. Divisão, separação, distância, caracterizam a sociedade em suas relações de força e de sentidos, tensionando a relação entre a casa e a rua. Entre eu, tu e ele. Significando espaços e lugares de muitas maneiras. (ORLANDI, 2017, p. 116) 
Indistinção entre casa e rua, indistinção no sujeito ("O malabares é o morador de rua e é o artista de rua" (idem, p. 116) e entre sujeitos ("Também, não há sempre uma separação estrita entre eu e tu, entre tu e eu, entre eu e ele"): "Há mistura, como forma de relação da alteridade. Insistimos em que não há esta separação estanque entre sujeitos, os limites são frouxos, e se desfazem (...)". (idem, p. 117).

O malabares analisado se autoidentifica como artista e morador de rua e diz que sua vida é o semáforo e que "Melhor fazer malabares do que estar matando os outros". Orlandi reconhece que seria necessária uma análise "mais aprofundada" dessa formulação, deixando aberta a possibilidade de que não se trataria só da reprodução de um "já ouvido" "mas também efeito do que ele nem sabe que ou como significa nele". Em suma, a narratividade, essa memória que se diz, lhe dá uma identidade ao se contar com relação ao outro e ao Outro (idem, p. 126), assim, no descentramento entre os sujeitos e nos sujeitos. Analisar a cidade seria observar esses efeitos de memória em funcionamento, que se dá na narratividade inscrita na tópica cívica - esta distinta do espaço empírico "factual".

Ao pensar no que a noção de memória se dizendo tem de político, por se dar em "processos identitários" como conceitua Orlandi, a narratividade é um modo de compreender o simbólico, portanto, relativo aos modos pelos quais o sujeito se identifica.

Necessário dizer que tais "processos identitários" diferenciam-se de um posicionamento de militância identitária, em voga nesses anos. No processo histórico de mudanças no mundo do trabalho, as pautas ditas identitárias (movimento gay, racial, de gênero etc.), por se constituírem como problemas concretos a serem enfrentados, ganham espaço e passam a atrair jovens militantes no século XXI. O fortalecimento dessas pautas é interpretado de inúmeras maneiras e, como movimento mais largo, entra pelos poros da $\mathrm{AD}$ e a faz aprofundar reflexões (ZOPPI-FONTANA, 2020, p. 33). A concepção de narratividade, que vai se estabelecendo durante essa década na obra de Orlandi, de certa maneira, dialoga com essa perspectiva na medida em que coloca as condições de produção do discurso como fundamentais às análises sobre os efeitos de sentido. Vale ressaltar que, muitas vezes aferradas à clássica ideia de luta de classes como motor da história, críticas a esses movimentos afirmam que "lugar de fala" prevê privilégio epistêmico daquele que o tem, silenciando o outro e inviabilizando o debate 
público. Sem entrar nesse debate, destacamos que a noção de narratividade - talvez diferentemente da ideia corrente de "lugar de fala" - não dá privilégio epistêmico ao sujeito: o dominado, apenas porque é dominado, não entenderia mais de dominação que qualquer outro. A narratividade, a janela na metáfora orlandiana, supõe apenas determinada perspectiva, a partir de certas condições de produção do discurso. A narratividade também não imporia o silêncio ao outro. Como "memória (que) se diz", a partir dos dispositivos teóricos da AD, de modo algum eliminaria a posição do outro nos efeitos de sentido. Ao contrário, como vimos, tem como mola propulsora do pensamento a exterioridade (o interdiscurso), a heterogeneidade como constitutiva, analisando o discurso na relação com o outro e com o Outro.

Nas relações do urbano, o que mostra Orlandi é que nos processos de individuação - desenhados em esquema (2012, p. 233) - a narratividade é um modo de ver funcionar efeitos de sentido nesses processos identitários. A "novidade" dos anos 2000 é que tais efeitos pesam menos sobre a divisão (do político) que sobre os processos de indistinção que recobrem essa divisão e que, ao mesmo tempo, permitem rupturas. De forma que, o "choque sinonímico" entre os nós memória e político, na relação entre essa "memória que se diz" com "o político", coloca-se em um momento de incômodo, quando o pensamento se depara com o fato de que uma memória que se diz, na divisão de sentidos, traz uma alteridade que a desidentifica, contraditoriamente.

Compreender como a memória se diz é explorar discursivamente as possibilidades de ruptura - em que há desidentificação - nos processos de individuação. $\mathrm{O}$ assunto não é novo, nem na $\mathrm{AD}$ pois Pêcheux já tratava de processos de desidentificação (PÊCHEUX, 1975), nem em outras caracterizações da subjetivação. Para Rancière, por exemplo, "Toda subjetivação é uma desidentificação, o arrancar à naturalidade de um lugar, a abertura de um espaço de sujeito onde qualquer um pode contar-se porque é o espaço de uma contagem dos incontados, do relacionamento entre uma parcela e uma ausência de parcela" (RANCIÈRE, 1996, p. 48). Por isso, especialmente quando pensamos no dissenso que se estabeleceria em uma arena comum da política, os sujeitos fazem-se como deslocados. ${ }^{10}$ Ao se inscrever, querendo ou não, em uma tradição brasileira que diagnostica Macunaíma, "o herói sem nenhum caráter", não só como um "mau-sujeito" na expressão 
pechetiana, mas como um sujeito sem nada que o defina, Orlandi tira da evidência consensual os sujeitos e seus sentidos, fazendo ver rupturas, mesmo que diminutas, na cidade.

Uma das recorrências de "político" no corpus é a articulação, em alguns casos o confronto, entre "o simbólico com o político". Articular o simbólico com o político, necessidade que a autora em A casa e a rua indica ter sido apontada por Pêcheux (1981), é papel do Estado na sociedade capitalista, ainda que seja posto como coadjuvante no colapso. Com suas instituições e discursos, é o Estado que individua, isto é, que faz que o indivíduo se constitua como sujeito ao se inscrever em determinados sentidos e não em outros, em determinadas formações discursivas. Como, para a autora, há sempre um laço nem que seja mínimo ("Os laços sociais se desvanecem. Mas a minha hipótese é de que sempre haverá a tentativa do sujeito, para individuar-se, de estabelecer um laço social mínimo que o signifique (E. Orlandi, 2008)”, essa que é a interpelação do indivíduo em sujeito pela ideologia ocorre pela falha do Estado. "O Estado falha e significa por esta falha" (ORLANDI, 2010, p. 18).

Enquanto dispositivo teórico, o "político" aparece articulado ao simbólico e tal articulação ganha um efeito de "funcionamento". Entretanto, quando entra nas análises, notamos que uma noção de confronto, não harmônico e diferente da ideia de representação - essa que garantiria que o simbólico representasse o político ontologicamente - instala-se. Assim, em Formas de individuação...(2010), na análise do tráfico, o simbólico e o político são postos em confronto e, em A casa e a rua... (2012), o confronto aparece na medida em que a análise se depara com o que o espaço tem de material. Não no sentido formal em que se trabalha a materialidade dividindo o que seja verbal e não verbal, mas material no sentido do real da história, das relações da cidade em seus movimentos como espaço de significação:

Pensando discursivamente a cidade, consideramos o espaço em sua materialidade. Desta perspectiva o espaço é, de um lado, "o enquadramento de todos os fenômenos" (P. Henry, e-mail pessoal) e, de outro, ele não é nem um vazio, nem apenas uma função, ele é espaço de interpretação, tem sua materialidade em que se 
confrontam o simbólico e o político. Assim, a cidade se materializa em um espaço que é um espaço significativo: nela, sujeitos, práticas sociais, relações entre o indivíduo e a sociedade têm uma forma material, resultante da simbolização da relação do espaço, citadino, com os sujeitos que nela existem, transitam, habitam, politicamente significados (ORLANDI, 2012, p. 200).

Destarte, quando a política acaba - no processo de colapso da modernização no qual por mais "progressista" que sejam os governos só conseguem ser, no máximo, bons gerenciadores da barbárie (OLIVEIRA, [2003] 2007) - o político, como divisão dos sentidos, entra em confronto com o simbólico dando lugar à indistinção como processo de significação dominante. Orlandi estampa, desse modo, os problemas de um real da história com o qual o analista se depara. (ALVES, 2020). Portanto, é possível dizer que memória e político circulem na dominância da indistinção. Nessa, o político não é representado pelo simbólico como no campo da argumentação.

Percorremos sentidos do nó memória e do nó político no corpus e compreendemos que suas possíveis relações se dão no instante do encontro - que pode ocorrer ou não - em que, em meio à indistinção, o modo "desidentificado" do sujeito se dizer mexe com a divisão de sentidos, desfazendo sentidos já estabelecidos.

Na relação tensa entre a segregação e o seu desejo de sociabilidade (ORLANDI, 2017, p. 122), embora Orlandi diga que o malabares não visa a aura, aquela explorada por Walter Benjamin, porque sua autenticidade se daria como "provável cidadão comum" (idem, p. 126), é pelo acontecimento (instalação) artística ${ }^{11}$ que esse corpo se presentifica "no seu possível 'outro' lugar" (idem, p. 127).

\section{2. $\mathrm{O}$ discurso e a cidade}

Pensemos agora no encontro entre cidade ( $1^{\circ}$ quadrante) e discurso ( $3^{\circ}$ quadrante). Atrai o nó cidade o texto Dancinha... (2015) que se encavala com A casa e a rua... (2012), aparecendo colado a público. Atrai o nó discurso o texto Formas de individuação... (2010), aparecendo junto a mundo. 


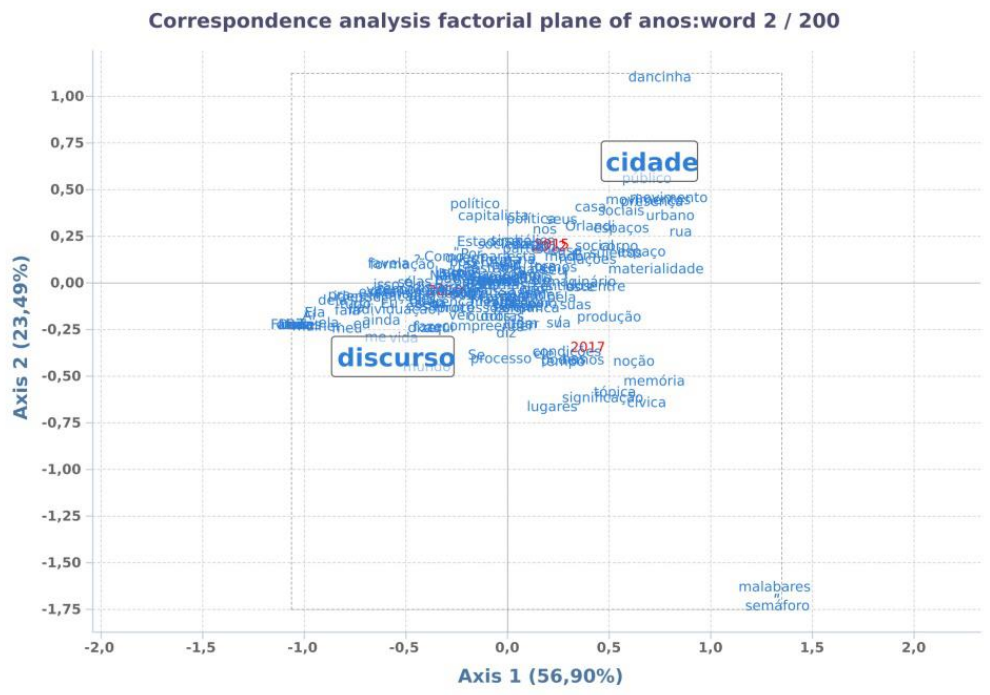

Fig 3.: Nó cidade, $1^{\circ}$ quadrante, e nó discurso, $3^{\circ}$ quadrante.

Em contato com o programa, observamos que a maior coocorrência de cidade é "real", termo que ocorre vinte vezes no corpus, sendo que em seis dessas vezes ocorre junto com cidade. Enquanto isso, o termo que mais ocorre junto a discurso, além do substantivo "análise", é o verbo "aparece". Enquanto cidade então carrega sentidos da história concreta e/ou de um lacaniano impossível, o discurso está vinculado a uma ação cujo sentido é o do tornar-se manifesto ou visível.

Iniciemos com o nó discurso.

O caso é o de uma mãe de um traficante que, preso em seu lugar, recebe dele seu posto de chefe do tráfico. Orlandi mostra como as distinções entre homem e mulher constituídas em uma formação capitalista "clássica" não funcionam na delinquência.

Voltemos à Dona Leda. Então, uma vez que o filho dela assumiu a prisão no lugar dela, ela assumiu, no lugar do filho na favela, a direção do tráfico. E aí está o centro de nossa atenção. Dona Leda funciona exatamente como funcionaria o traficante que estivesse no lugar dela. Não 
aparece o discurso da diferença ou da igualdade: se assume. $\mathrm{O}$ que se percebe é isso: em termos ideológicos, em um caso, se está dentro de um mundo capitalista que tem uma certa representação de valores e se fica discutindo esses valores. Quando se chega em um lugar desses aqui, no espaço da delinquência, não tem essa mediação, quer dizer, é uma outra formação discursiva claramente. Não se discute se é homem ou mulher. Aqui a gente percebe que quem está estranhando é o narrador; mas, na ação, não se discute ou se distingue quem é quem [...] (ORLANDI, 2010, p. 25)

Não se fala sobre o discurso em geral, mas sobre um discurso que "aparece". No caso, o da diferença dos sexos.

"E apesar de amigos e apesar dela ser a responsável pela favela e de bancar advogados e ajudar os presos, havia um grande preconceito contra ela. Por isso que ela não podia facilitar" [narra MV Bill]. Aí estão narradas as condições de produção. Observem a situação em que isso é dito: aí aparece o discurso da diferença. Mas é interessante atentar ao como é que ela responde, como é que ela está se colocando aí. (idem)

Enquanto no presídio os valores desse discurso da diferença valem e a regra é para todas as mulheres, fora da cadeia não há diferença: Dona Leda é a chefe de todo o aparato de produção e refino de cocaína, fazendo tudo o que um homem faz naquele espaço.

O discurso como efeito de sentido, como ideologia se materializando, repete-se quando MV Bill vai a ela argumentar pela vida de um desafeto, que irá morrer: "E o discurso da preservação da vida, quando o Bill fala, "aparece" como um discurso "moralista". No discurso de Dona Leda não há moralismo. Ela apenas diz: 'Você sabe o que ele fez? Alcaguetou. Então, morre."' (ORLANDI, 2010, p. 31).

Fica evidenciado que o discurso de MV Bill "aparece" porque está em relação a outro, ao de Dona Leda. Esse aparecer do discurso é também resultado, na análise, de um afastamento do analista em sua 
posição de entremeio. Quando a outra personagem analisada, Eva, que faz sexo oral nos traficantes, conta do trauma de sua mãe com os homens pois quando, grávida dela, teria o flagrado com um homem na cama, o discurso "aparece" de uma forma e tal manifestação é efeito da análise:

"Eu não tenho essa vergonha de ter um pai "viado". Respeito ele como meu pai, mas não conheço". Quer dizer, tudo isso aparece em seu discurso como parte de sua "opinião" mas é só lembrança, é só relato [...] (idem, p. 37).

Da onde a questão do recorte (ORLANDI, 1984), do construto teórico. Assim, o discurso "aparece" pela pergunta do analista ao mesmo tempo em que se faz inapreensível nas condições dadas pela segregação.

Porque este real não é homogêneo, não é facilmente accessível, nem mesmo reconhecível. São muitos os seus discursos. E o discurso sobre e da violência, como tenho dito, aparece como homogêneo e dominante. Consensual. O que não encontramos quando entramos nos discursos do tráfico, das boqueteiras, da favela. O discurso da violência aparece como homogêneo e dominante, mas quando analisamos Dona Leda vimos o domínio que ela tem do espaço que ocupa na favela, enquanto a boqueteira se identifica através do Falcão, em uma posição-sujeito mulher distinta. Mas insistimos em "olhar" pelas nossas formações discursivas. Como não há simetria, não há possibilidade de transferência de sentidos. Não há compreensão. [...] O modo de existência desses sujeitos, assim como o funcionamento do que estrutura a formação social em que vivem permanece para nós invisível. Além de nossas boas intenções "consensuais", de "inclusão" das "minorias" (idem, p. 40). 
Note-se que o modo de existência desse outro é inapreensível não exatamente pela análise, mas pelas políticas públicas que tentam mudar a organização do espaço urbano a partir de proposições de "consenso". A análise não deixa de ser uma posição assumida, mas tal posição deve ser de entremeio, entre as diversas formações discursivas. Entretanto, é importante também notar que, para Orlandi, a análise não é passível de generalização. Essa compreensão, que é a do gesto de interpretação, não se confunde, porém, com um relativismo que nega um "real da história", mas entende a história como demandante de sentidos ("os fatos reclamam sentidos. E isto é a história (HENRY, 1997 apud ORLANDI, 2010, p. 11)).

Junto a esse nó discurso - que "aparece" pelas relações ideológicas de real concreto e que não se generaliza - está na AFC o nó mundo.

Se para Pêcheux o discurso é efeito de sentido entre locutores, cremos poder dizer que, para Orlandi, por trabalhar a segregação, o discurso é efeito de sentido entre mundos. Na segregação, não se trata de posições diferentes dentro de um mesmo espaço de enunciação, mas de mundos diferentes. Os gestos de delinquência, ilegíveis aos outros mundos, são gestos que tornam aquele mundo habitável (ORLANDI, 2010, p. 19). Há o "mundo do crime". Há o "mundo da favela" (idem, p. 39). A pichação ata o sujeito ao "mundo da significação" (idem, p. 19). Não é coincidência que dada a hecatombe ecológica se possa enunciar que o que exista seja uma "guerra de mundos" (DIAS; SZTUTMAN; MARRAS, 2014, p. 508), de "modos de existência" em tudo distintos, a afetar a relação entre as inúmeras formações discursivas.

Se, por um lado, como vimos, o discurso "aparece" na relação do simbólico e do imaginário, a cidade em Orlandi deve se ver com um "real". Passemos, pois, a observar as coocorrências de cidade e real.

Em nossos estudos e pesquisas, sobre cidade, distinguimos o que é ordem e organização. Reservamos a noção de ordem para o real da cidade, com seus movimentos, sua forma histórica, seu real. Já a organização, que chamamos de organização urbana, está ligada ao imaginário projetado sobre a cidade, tanto pelos seus habitantes como pelos especialistas do espaço, como urbanistas, administradores etc. 
que, assim, se relacionam com a cidade através desse imaginário, organizando o espaço da cidade, planejando-o, calculando-o de maneira empírica ou abstrata de acordo com seus objetivos. Em geral, ignorando, silenciando as reais necessidades histórico-materiais do espaço enquanto instância real, própria à cidade que está sempre em movimento.

Para repor a relação com o real da cidade em nossos estudos e pesquisas, estamos propondo pensar a relação básica entre a casa e a rua (ORLANDI, 2012, p. 199).

Vê-se que o par casa/rua, interpretado pela relação público/privado em 2012, vem "repor" o que se considera a ordem - uma instância real, não imaginária - da cidade. No conjunto da obra, recoloca-se a questão de quanto mais muros, mais violência. Acentua-se que, a despeito e por causa das separações, "as relações sociais estão se tornando indiscerníveis e tensas" (idem, p. 200).

Orlandi, que já vinha afirmando a sobreposição do urbano sobre a cidade, e, portanto, que já diferenciava relações sociais das relações do urbano como espaço preenchido, calculado e administrado, compreende esse real com suas contradições cada vez mais expostas pela indistinção. Interessante notar que a indistinção é um objeto a ser interpretado de modo privilegiado no Brasil. Por exemplo, a dificuldade de distinção entre o público e o privado no país é realçada por Sérgio Buarque de Holanda, em Raízes do Brasil ([1936] 1995). O autor mostra que o Estado nasce pela transgressão da ordem doméstica e familiar. Ou seja, o indivíduo só se torna eleitor e elegível, responsável pelas leis da Cidade, quando a ordem familiar é abolida. O conflito entre Antígona e Creonte seria a maior expressão dessa intensa incompatibilidade entre o público e o privado:

Creonte encarna a noção abstrata, impessoal da Cidade em luta contra essa realidade concreta e tangível que é a família. Antígona, sepultando Polinice contra as ordenações do Estado, atrai sobre si a cólera do irmão, que não age em nome de sua vontade pessoal, mas da suposta vontade 
geral dos cidadãos, da pátria: [...] (HOLANDA, [1936], 1995, p. 141).

A impessoalidade do serviço público, segundo o autor, nunca teria predominado sobre as relações particulares desse que foi caracterizado como um "homem cordial". Até para conseguir realizar negócios com o brasileiro, seria preciso dele se tornar amigo. Essa confusão que, no Brasil, "se faz acompanhar de crises mais ou menos graves e prolongadas" (idem, p. 142), afeta profundamente os sentidos no espaço urbano ao longo do tempo. Tomando a literatura como modo de compreensão desse real da cidade, ainda em família, Chico Buarque já em "Estorvo", romance do início dos anos 1990, mostra um sítio do narrador ser estranhamente ocupado por desconhecidos, entre idosos e crianças com camiseta "Só Jesus salva", envolvidos em atividades ilícitas. Se o privado não se sustentava já no fim dos anos 1980, no mais recente "Essa gente", de 2019, as ruas tampouco são públicas. O esporte do ricaço é espancar mendigos que estão apenas encostados no muro da calçada do clube e o escritor/protagonista mal consegue se movimentar sozinho nas vielas do morro.

Em Orlandi, por certo, a indistinção entre o público e o privado já aparecia em Cidade dos sentidos (2004). O muro já era visto como uma violência simbólica que gerava indistinção entre um e outro: tudo o que é exterior é hostil e, por isso, passa-se a pedir a identificação de quem está fora (causa de estranhamento: "Ora, como um cidadão igual a mim se arvora no direito de pedir-me um documento de identidade?" (ORLANDI, 2004, p. 91)) e, por dentro do condomínio, também se cria a indistinção. Com A casa e a rua... (2012), Orlandi volta a investir nesse tema.

Importante destacar que essa noção ocorre de formas diferentes conforme as divisões de sentido: a indistinção não tem o mesmo sentido na favela e no condomínio. No interior da favela, traficantes e moradores são igualmente alvos para a violência do Estado em recorrentes chacinas que matam indistintamente. Na periferia, a indistinção "vai na direção de elidir a propriedade, o espaço privado" (ORLANDI, 2012, p. 208): a casa é "continuamente devassada, não funciona como propriedade privada e está sujeita à violência todo o tempo" (idem). Já no condomínio, 
a direção do sentido é outra: a indistinção vai no sentido de aumentar o poder da propriedade, alargando o sentido e o espaço do privado (em condomínio, há domínio), às expensas do espaço público, significado neste caso como espaço de ninguém, o da violência, da segregação, da hostilidade (ORLANDI, 2012, p. 208).

O que se elide, nos dois casos, segundo Orlandi, é o espaço público que, em seus termos, torna-se "rarefeito". Os pichadores, que se individuam pelo sinal que o inscrevem, este que os liga simbolicamente a si mesmos e aos seus, são sujeitos que transitam por essas indistinções "diluindo sentidos". O muro, propriedade privada, na rua, não é público? Como a autora aponta, a indistinção funciona "sempre a favor do mais forte" (idem, p. 211).

Segundo Harvey, na contemporaneidade volta-se ao capitalismo por espoliação. Para monopolizar fontes que permitem extração de valor, o capital precisa estabelecer relações predatórias, extrativistas, como se estivéssemos voltando ao cercamento dos campos, inicial do processo de mercantilização, agora também nas cidades. "A urbanização, podemos concluir, vem desempenhando um papel fundamental no reinvestimento dos lucros, a uma escala geográfica crescente, mas ao preço de criar fortes processos de destruição criativa que espoliaram as massas de qualquer direito à cidade" (HARVEY, 2013).

O discurso urbanista da administração utiliza a indistinção dos sentidos a seu favor, nesse processo de espoliação, em seu canteiro de obras. Todavia, o que mostra Orlandi é que esse imaginário sobre o urbano entra em choque com o real da cidade cujos sujeitos não desistem de sua condição de seres simbólicos. Contra quem prega mais muros, mais vigilância e mais armas, Orlandi mostra que fora do social, individualmente, nunca haverá solução para a violência.

Ao invés de recuarmos, histórica e politicamente, para o interior de espaços fechados, temos de conquistar o espaço-tempo de nossa contemporaneidade social e política que é habitar a cidade sem restrições: nosso lugar público, social, político. E aí poderemos nos sentir em casa, onde estivermos. Com nossos concidadãos. 
Nossos iguais. Em uma sociedade que seria, aí sim, democrática (ORLANDI, 2012, p. 212).

Ao considerar, portanto, que quando falamos em discurso pensamos em efeitos de sentido entre mundos e quando falamos em cidade pensamos no seu real, em seus movimentos, em seus fluxos, no transitar de sujeitos que fissuram o discurso urbano, onde a possível sinonímia entre discurso e cidade? Em outras palavras, onde o real da cidade aparece no discurso?

Os objetos de análise dão a justificativa ao recorte.

Ao localizar a dancinha, Orlandi cita a leitura de Muniz Sodré sobre Deleuze e Guattari que conceitua minorias como "um lugar onde se animam os fluxos de transformação de uma identidade ou de uma relação de poder" (ORLANDI, [2015] 2017, p. 136). Para Orlandi, os sindicatos, por exemplo, não entram nessas minorias. Não detém sua análise em agrupamentos que organizam o ressentimento social por uma "gestão" da crise. Tampouco estaciona em movimentos de "minorias" que colocam o sujeito-em-si como centro, suas reivindicações como autoevidentes e a ocupação do espaço público como fim (idem, p. 144). De tal modo, não inscreve a dancinha como ato de "resistência":

A dancinha entra, para mim, na perspectiva da latência e da formulação de um gesto de sobrevivência (não chamo de resistência, nesse caso). E a busca da ocupação do espaço público é assim percebida, porque estas análises, feitas dentro deste modelo de explicação, que se veste de "relações democráticas", só se ocupa do imaginário destas relações. Eu diria que o que se busca é uma afirmação como sujeito simbólico, histórico e social. E uma valorização real das relações sociais, enquanto vínculos sociais, sobrevivência (ORLANDI, [2015] 2017, p. 143).

Nesse momento, a ideia "resistência" é identificada a uma formação discursiva que diz das relações sociais em formas imaginárias. Essas formas seriam as de democratização das relações sociais a partir de uma 
ideia ética e liberal que, diga-se de passagem, nunca estaria "bem colocada" no país. ${ }^{12}$

Percebe-se que, a partir dos anos 2010, há um deslocamento da ideia sob a forma de "resistência" para a de "sobrevivência".

Em Formas de individuação... (2010), a resistência é entendida como o processo de interpelação do sujeito pelo Estado que torna possíveis as rupturas ${ }^{13}$. A delinquência, tal qual compreendida, adquire esse sentido de resistência: “(...) a noção de delinquência já vem definida pelo modo da segregação e que quando a pensamos de outro modo, podemos compreendê-la enquanto forma de resistência e então seu sentido é outro." (ORLANDI, 2010, p. 15). Posteriormente, com Dancinha... (2015), o que é denominado resistência continua a ser remetido a furos na ideologia nos processos de constituição das posições-sujeito. Porém, o termo não é aplicado ao discurso em análise. Por fim, "resistência" deixará de aparecer no texto posterior, quando analisa os malabares que sobrevivem do que ganham no semáforo. Desse modo, nos anos 2000, a "sobrevivência" passa a dar o tom da análise.

Mais detalhadamente, em Formas de individuação... (2010), como já dissemos, a delinquência seria o "a-mais necessário para a sobrevivência" (ORLANDI, 2010, p. 14 e 2017, p. 122), marcando a contradição entre o que excede, o supérfluo (a-mais) e a necessidade, como ele próprio excede (resto) mas ao mesmo tempo é necessário para manter a sociedade brasileira com seus serviços baratos (faxina, entregas a domicílio...). Aqui, a delinquência é resistência, entretanto o termo já desliza para a sobrevivência.

Em Dancinha...([2015] 2017), como vimos, "sobrevivência" metaforiza "vínculos sociais" ("E uma valorização real das relações sociais, enquanto vínculos sociais, sobrevivência." (ORLANDI, [2015] 2017, p. 143)).

Em Malabares... (2017), os trocados recebidos no farol significam sua sobrevivência. $\mathrm{O}$ equipamento semáforo é seu lugar de trabalho, "nicho de sobrevivência", e, muitas vezes, sua casa, pois ali também dorme (ORLANDI, 2017, p. 114). Aqui, a sobrevivência metaforiza a "não desistência". Desloca-se o imaginário das relações democráticas (de "inserção" dessas camadas sempre aviltadas) pelo perscrutamento dos modos de afirmação desses sujeitos como simbólicos, históricos e sociais. 
Há, portanto, uma lucidez que não se deixa envolver por nenhum tipo de romantização do que sejam "relações democráticas" muitas vezes travestidas com o véu da cultura. ${ }^{14} \mathrm{~A}$ dancinha não é apenas a cultura do gueto, mas sua forma de existência, meio de sobrevivência.

Nesse sentido, tal como Antonio Candido observa na poesia de Carlos Drummond de Andrade, é da descrição seca do cotidiano na cidade, sem o sentimentalismo programático de resistência, que nasce a força expressiva da análise ${ }^{15}$. Essa parece ser a direção dada pela autora, que, como o poeta a andar de branco pela cidade cinza (indistinto dela) só pode se interessar pela flor, mínima, a brotar do asfalto:

Preso à minha classe e a algumas roupas,/ vou de branco pela rua cinzenta./ Melancolias, mercadorias espreitam-me. (...) Uma flor nasceu na rua! (...) É feia. Mas é uma flor. Furou o asfalto, o tédio, o nojo e o ódio (ANDRADE, [1945] 2003, p. 27).

Ao se atentar a como os sujeitos se juntam pelas margens nesses movimentos, assim como analisa a pichação, o que busca é a afirmação do sujeito simbólico criando vínculos históricos e sociais. Para isso, outra noção mobilizada é a da presença, que é o modo como o espaço significa nos corpos:

Sentimos nosso corpo, presença. Significamos em nosso corpo. Significamo-nos em nosso corpo. Esta sensação produzida pelos efeitos de sentido do palco-Favela em nós, parte das condições de produção. Uma "sensação" que é, dada a materialidade do espaço, o modo como ele se presentifica, significa em nós (ORLANDI, [2015] 2017, p. 132).

O discurso da dancinha faz-se, portanto, como presença da Favela ("Por que a rua, a céu aberto, não é espaço público para favelados?" (ORLANDI, [2015] 2017, p. 140)) presença que se faz no lugar do outro na medida em que esse espaço não é, de fato, público. (“[...] para eles não há espaço privado, e o espaço da rua / público é onde correm risco. 
Eles rezam e se benzem quando vão para a Rua" (idem, p. 146)). O espaço material "Favela" (assim, com letra maiúscula) é simbolizado nos corpos dos que lá moram e vêm para a rua do "Bairro" (idem, p. 133). Favela é, desse modo, não o espaço empírico mas ideologicamente significada fazendo-se como presença nos corpos. Por isso, a autora utiliza letras maiúsculas para falar de Rua, Favela, Bairro, Pancadão, Fluxo... Para marcar cada palavra como sendo uma "palavradiscurso" que reverbera sentidos para muitos lugares (idem, p. 139).

Articulada à latência, que tem a ver com a possibilidade do semsentido vir a ser um sentido outro (idem, p.137), a presença também significa com relação ao outro. O "pode copiar agora" enunciado pelo sujeito do rolêzinho que grava na esquina seus passinhos e os posta na internet faz eco no outro (na classe média que o imita) retornando a si diferentemente. No caso do malabares, sua presença é submetida ao ritmo do farol a ditar os Fluxos na cidade:

A inevitável materialidade do sujeito na história (corpo e sentido) anuncia a sua presença irremediável, no seu possível "outro" lugar. Corpo em presença no espaço público. Fazendo malabarismo. Na duração ditada pelo semáforo, no fluxo de Rua, enquanto fulgurar seu espaço e tempo... Que pode desaparecer sob a forma do policial que o expulsa, do motorista que quase o atropela, ou daquele que lhe dá um trocado e que o mantém no mesmo lugar (ORLANDI, 2017, p. 127).

A partir do que o programa TXM nos deu, tentamos verificar as possibilidades de sinonímia entre os nós discurso e cidade. Ou melhor, como o discurso como acontecimento e a cidade em seu real tocam-se em uma sinonímia.

Compreendemos que a própria dancinha - que movimenta mais braços e pernas diferentemente da sensualidade do funk - significa esse encontro ("efeito metafórico da necessidade de existir, de movimentarse, de expandir-se. Fluxo." (ORLANDI, [2015] 2017, p. 147)) sinonímico entre o "discurso e real da história" que é o subtítulo do livro $E u, T u$, Ele que traz esse ensaio. É no Fluxo que o discurso acontece como real - esse que escapa, rompe com o discurso do urbanista - na 
indistinção dos sentidos e rarefação do espaço público, formando esses laços estritamente necessários à sobrevivência, em meio à violência policial e ao extermínio de seus corpos. ${ }^{16}$

\section{Conclusão}

Os anos 2010 na análise de discurso brasileira sobre a cidade buscou o Fluxo, a presença dos corpos em movimento, a dancinha, o malabares, movimentos da sociedade em seu funcionamento urbano. Em época marcada pelos protestos de 2013, em vez de escrever sobre aquelas expressivas manifestações e seu caleidoscópio de sentidos a antever resultados na política nacional, Eni Orlandi aponta sua interpretação para a compreensão das formas de assujeitamento pelo comum, ao se interessar pela "garotada da periferia [a] fazer lazer a céu aberto, na via pública". Ao analisar a ordem dos laços estabelecidos no espaço urbano em seus fluxos, busca compreender de fato, e não empiricamente, "verdades singelas" tais quais aquelas que estimulam uma interpretação mais ligada à história das ideias, a longo termo, sobre como se dão os processos de subjetivação de nossa gente por esse Estado que falha:

Podemos ensaiar a organização de nossa desordem segundo esquemas sábios e de virtude provada, mas há de restar um mundo de essências mais íntimas que, esse permanecerá sempre intato, irredutível e desdenhoso das invenções humanas. Querer ignorar esse mundo será renunciar ao nosso próprio ritmo espontâneo, à lei do fluxo e do refluxo, por um compasso mecânico e uma harmonia falsa (HOLANDA, [1936] 1995, p. 188).

Sem utilizar nenhum compasso mecânico nesse sentido, o subtítulo do ensaio sobre a dancinha "Ou: Uma rua chamada Terra Brasileira, na zona leste de São Paulo" faz ranhura dando espaço para o surgimento de "uma possibilidade projetiva de povo" (ORLANDI, [2015] 2017, p.144). Pensando na instância do comum em sua obra (2004), povo não é entendido no sentido populista. Povo aparece como uma noção que permite pensar laços e, sobretudo, um futuro, isto é, uma outra ordem de coisas. Diz: "Sem uma possibilidade projetiva de povo, o vínculo 
social perde o sentido." (idem). E ainda: "Sem povo, não se pode projetar a sociedade na história" (idem). Sobre isso, como síntese desses modos de existência, um importante trecho repete-se no ensaio Dancinha... ([2015] 2017) e em Malabares... (2017):

$\mathrm{Na}$ força das coisas, produzem a sobrevida pelos laços que, mesmo na dessignificação dos processos de ser, na rarefação do chamado sistema social, narram a não desistência, sua sobrevivência como povo (ORLANDI, [2015], 2017, p.150).

$\mathrm{Na}$ força das coisas, produzem a sobrevida pelos laços que, mesmo na dessignificação dos processos de ser, na rarefação do chamado sistema social, eles narram, como não desistência: sua sobrevivência como sujeitos (ORLANDI, 2017, p. 127).

Acima, o efeito metafórico vai de "povo" a "sujeitos".

"Povo" prevê, como vimos, uma perspectiva de futuro em que os sujeitos se vinculam socialmente entre si. Já "sujeitos" em AD são aqueles que têm relação direta com a ideologia na medida em que resultam da interpelação dos indivíduos por ela e, portanto, são também assujeitados pelas ilusões de serem fonte do sentido e da realidade dos seus pensamentos. Tudo isso que compõe o sujeito é descentrado, despossuído pela análise que vai revelar a ideologia considerada como o que é tomado como evidente. Esse sujeito não necessariamente diz respeito a uma projeção de futuro, que se perde nesse deslocamento.

Não se pode negar, como tentamos mostrar pela análise, a possibilidade de que cidade e discurso se toquem quando este aparece como o real da cidade, rompendo com o discurso do urbanista, aproveitando-se da indistinção entre o público e o privado como forma de sobrevivência do sujeito a estabelecer vínculos simbólicos. Igualmente, não se pode negar a possibilidade do encontro da memória com o político quando o sujeito, ao se contar, em sua narratividade, desestabiliza as divisões pré-estabelecidas pela ideologia, instaurando um momento de sentido comum.

Porém, o deslocamento de "povo" a "sujeitos" deixa linhas em aberto. Lida em época em que não se coloca mais o desejo de ascensão, 
mas apenas o de "um lugar ao sol" - em que a ideia de progresso/inclusão apenas se enuncia em falas de políticos profissionais que tentam (se) iludir com a promessa de uma restauração impossível, mas que não se enuncia nas falas do menino do passinho que diz querer ser funkeiro (o que já é) ${ }^{17}$ quando crescer - o amanhã não faz laço. Portanto, mesmo com o topar com a flor na cidade, nesta "terra remissa e algo melancólica" como observaram os primeiros observadores europeus (HOLANDA, [1936] 1995, p. 151), pelas questões que Orlandi suscita, um efeito saturnino resta excedendo, dialeticamente, a leitura desse arquivo.

\section{Referências bibliográficas}

ALEXANDER, M. (2018) A nova segregação: racismo e encarceramento de massa. Trad: Pedro Davoglio. Revisão técnica e notas: Silvio Luiz de Almeida. São Paulo: Boitempo, 2018.

ALVES, M. (2020). Osso de borboleta: leitura discursiva do Fundo Michel Pêcheux pela textometria. Tese. Doutorado em Linguística. Campinas: Universidade Estadual de Campinas, 2020.

ANDRADE, C. (2003). A rosa do povo. 27 ed. Rio de Janeiro: Record. CANDIDO, A. (1999). Iniciação à literatura brasileira: resumo para principiantes. 3. ed. São Paulo: Humanitas/ FFLCH/USP, 2003.

COURTINE, J. "Definição de orientações teóricas e construção de procedimentos em Análise do Discurso". In: Policromias - Revista de Estudos do Discurso, Imagem e Som, [.S.l.], v. 1, n. 1, set. ISSN 24482935. [1982] 2016. Disponível em: https://revistas.ufrj.br/index.php /policromias/article/view/4090. Acesso em: 08 jun. 2019.

DIAS, J. P.; SZTUTMAN, R.; MARRAS, S. "Múltiplos e animados modos de existência: entrevista com Bruno Latour". In: Revista de Antropologia, [S. 1.], v. 57, n. 1, p. 499-519, 2014. DOI: 10.11606/2179-0892.ra.2014.87772. Disponível em: https://www.revistas.usp.br/ra/article/view/87772. Acesso em: 22 mai. 2021.

FELDMANN, D. A "normalidade" é a raiz dos riscos que afligem a humanidade. Entrevista ao Instituto Humanitas Unisinos. 2020 Disponível em: http://www.ihu.unisinos.br/599790-a-normalidade-e-araiz-dos-riscos-que-afligem-a-humanidade-entrevista-especial-comdaniel-feldmann-em-edicao Acesso em: 31 mai.2021. 
GUIMARÃES, E.; ORLANDI, E. "Unidade e dispersão: uma questão do texto e do sujeito". In: ORLANDI, E. Discurso e leitura. $8^{\text {a }}$ edição. São Paulo: Cortez, p. 53-73. (1980) 2008.

HARRIS, Z. "Discourse Analysis". In: Language, Vol. 28, No. 1 (Jan. - Mar., 1952), pp. 1-30. Published by: Linguistic Society of America Stable 1952. Disponível em http://www.jstor.org/stable/409987. Acesso em 31 mai.2019.

HARVEY, D. "O direito à cidade”. In: Piauí. Edição 82, 2013. Disponível em: https://piaui.folha.uol.com.br/materia/o-direito-acidade/ Acesso em: 1 jun.2021.

HENRY, P. "Os fundamentos teóricos da "análise automática de discurso" de Michel Pêcheux (1969)". In: HAK, Tony (Org.) Por uma análise automática do discurso: uma introdução à obra de Michel Pêcheux. 4a edição. Campinas: Editora da Unicamp, 2010.

HOLANDA, S. B. Raízes do Brasil. São Paulo: Companhia das Letras. $26^{\mathrm{a}}$ ed. 1995.

HOLlANDA, F. B. Estorvo. São Paulo: Companhia das Letras. 1991. HOLLANDA, F. B. Essa gente. São Paulo. Companhia das Letras, 2019.

IBGE. Censo 2010: Estatísticas de Gênero mostram como as mulheres vêm ganhando espaço na realidade socioeconômica do país. 2014. Disponível em: https://censo2010.ibge.gov.br/noticiascenso?busca $=1 \& \mathrm{id}=1 \& \mathrm{idnoticia}=2747 \& \mathrm{t}=$ estatisticas-generomostram-como-mulheres-vem-ganhando-espaco-realidadesocioeconomica-

pais\&view=noticia\#: :text=A\%20taxa\%20de $\% 20$ formaliza $\% \mathrm{C} 3 \% \mathrm{~A} 7$ $\%$ C3\%A3o\%20no,58\%2C6\%25\%20em\%202010. Acesso em: 31 mai de 2021.

IBGE. PIB cai 3,5\% em 2015 e registra R\$ 6 trilhões. 2017. Disponível em: https://agenciadenoticias.ibge.gov.br/agenciasala-deimprensa/2013-agencia-de-noticias/releases/17902-pib-cai-35-em-2015-e-registra-r-6-trilhoes Acesso em: 31 mai de 2021. LIN, N. Número de moradores de rua cresce $60 \%$ em relação a 2015 em São Paulo. 2020. Disponível em: https://agenciabrasil.ebc.com.br/radioagencianacional/acervo/direitos-humanos/audio/2020-01/numero-de- 
moradores-de-rua-cresce-60-em-relacao-2015-em-sao-paulo/ Acesso em: 31 mai.2021.

MANIR, M. 'Nóis é prateado' para ganhar nova identidade social. In: O Estado de S. Paulo, São Paulo, 20/07/2015.

MILNER, Jean-Claude. Os nomes indistintos. Trad.: Procópio Abreu. Rio de Janeiro: Companhia de Freud. (1983) 2006.

NÉE, É. et al. Méthodes et outils informatiques pour l'analyse des discours. Rennes: PUR - Presses Universitaires de Rennes. 2017.

OLIVEIRA, F. "Política numa era de indeterminação: opacidade e reencantamento". In: OLIVEIRA, F.; RIZEK, C. (Orgs.). A era da indeterminação. Coleção Estado de sítio. São Paulo: Boitempo, (2003) 2007. p. 15-45,

ORLANDI, E.; GUIMARÃES, E.; TARALLO, F. Vozes e contrastes: discurso na cidade e no campo. São Paulo: Cortez, 1989.

ORLANDI, E. Interpretação: Autoria, leitura e efeitos do trabalho simbólico. $2^{a}$ edição. Petrópolis: Editora Vozes, 1996.

ORLANDI, E. Cidade dos Sentidos. Campinas: Pontes, 2004.

ORLANDI, E. "Formas de individu ${ }^{18}$ ação do sujeito feminino e sociedade contemporânea: O caso da delinquência". In: ORLANDI, E. (Org.). Discurso e políticas públicas urbanas: A fabricação do consenso. Campinas: Editora RG, 2010. p.11-42.

ORLANDI, E. "Dancinha: da rarefação do espaço social para as ruas. Ou uma rua chamada Terra Brasileira, na zona leste de São Paulo". 2015 (Texto apresentado no ENELIN, Univás, 2015).

ORLANDI, E. "Malabares - a relação entre espaços: o factual e a tópica cívica". In: ORLANDI, E. Eu, Tu, Ele: Discurso e real da história. Campinas: Pontes Editores, 2017, p. 113-127.

ORLANDI, E. "A casa e a rua: uma relação política e social". In: ORLANDI, E. Discurso em Análise: Sujeito, Sentido, Ideologia. Campinas: Pontes Editores, 2012. p. 199-212.

PÊCHEUX, M. “Análise automática do discurso (AAD-69)”. In: HAK, Tony (Org.) Por uma análise automática do discurso: uma introdução à obra de Michel Pêcheux. $4^{\mathrm{a}}$ edição. Campinas: Editora da Unicamp. (1969) 2010.

PÊCHEUX, M. In: PÊCHEUX, M. Semântica e discurso: uma crítica à afirmação do óbvio. Campinas: Editora da Unicamp, (1975) 2009. RANCIÈRE, J. O desentendimento: política e filosofia. São Paulo: Editora 34, 1996 
ROBIN, R. "Uma crítica da História, uma vontade de saber como os linguistas que se interessam pelo discurso trabalham" Entrevista a Guilherme Adorno de Oliveira. In: ADORNO et al. (Org.) (2019) Encontros na análise de discurso: efeitos de sentidos entre continentes. Campinas: Unicamp. 2019, p. 139-159

SCHERER, A.; SOUSA, L.; MEDEIROS, V.; PETRI, V. “O lugar dos estudos franceses na constituição de uma memória da Análise de Discurso no Brasil”. In: Letras, v. 24, n. 48, p. 13-28, jan./jun. Santa Maria: UFSM, 2014.

SCHWARZ, R. "As ideias fora do lugar". In: SCHWARZ, R. Ao vencedor as batatas. São Paulo: Duas Cidades, 4. ${ }^{a}$ ed. (1977) 1992.

TXM. (2020). Téxtometrie: Fédération des recherches et développements en textométrie autour de la création d'une plateforme logicielle ouverte. Disponível em: http://textometrie.enslyon.fr/?lang=en. Acesso em 1 jun.2021. ZOPPI-FONTANA. M. "Mulheres em discurso: linguagem, política e verdade.” Entrevista. In: Heterotópica, v. 2; n. 1, jan.-jul. 2020. ISSN: 2674-7502.

\section{Notas}

* Doutora em Linguística pela Universidade Estadual de Campinas (UNICAMP).

1 O PIB brasileiro cai 3,5\% em 2015, com retração em todos os setores, menos na agropecuária. Naquele momento, tratava-se da maior queda em 25 anos, desde o início da série em 1996 (IBGE, 2017).

2 "Exército dispara 80 tiros em carro de família no Rio e mata músico" (Folha de S. Paulo, 8/04/2019). Seria ainda possível chamar isso de "sociedade"?

${ }^{3}$ Considerada no longo decorrer da história, a ideia de identificar sentidos a partir dos contextos nos quais os termos ocorrem já era trabalhada no século XVII por Saint Chef sobre o texto bíblico (NÉE et al., 2017, p. 143).

4 "Em outros termos, propusemos um procedimento e não uma teoria da língua, entendendo-se que esse procedimento repousa sobre pressupostos teóricos que exigem precisamente ser explicitados e criticados pelo linguista". (PÊCHEUX, [1969] 2010, p. 124).

5 O caráter permanente de exceção das economias subdesenvolvidas apontado pelo sociólogo Francisco de Oliveira também explica, ao nosso ver, muitas das nossas particularidades pois: "Como disse Walter Benjamin, os oprimidos sabem do que se trata. O subdesenvolvimento finalmente é a exceção sobre os oprimidos: o mutirão é a 
autoconstrução como exceção da cidade, o trabalho informal como exceção da mercadoria, o patrimonialismo como exceção da concorrência entre os capitais, a coerção estatal como exceção da acumulação privada, keynesianismo avant la lettre." (OLIVEIRA, [2003] 2007, p. 131).

${ }^{6}$ Para Z. Harris não interessa apenas a frequência das palavras, mas, sobretudo, como ocorrem, isto é, em que "environment" ocorrem (HARRIS, 1952, p. 5).

7 Disponível em: https:// www.cartacapital.com.br/politica/o-governo-dilma-eextremamente-repressivo-4045/. Acesso em 1 mai.2021.

8 O esquecimento, constitutivo da memória para a $\mathrm{AD}$, está no apagamento de determinados sentidos e não de outros e também, no caso da delinquência, como funcionamento na segregação. A dedicatória de Alexander, por exemplo, toca no esquecimento: "Por fim, mas definitivamente não menos importante, estou escrevendo este livro para todos aqueles presos no interior do mais recente sistema de castas da América. Você pode estar trancafiado no interior ou para fora da sociedade bem estabelecida, mas você não está esquecido." (Prefácio a ALEXANDER, 2018).

9 Todos os negritos nas citações são nossos destaques. 10

"Mulher" em política é o sujeito de experiência - o sujeito desnaturado, desfeminizado - que mede a distância entre uma parcela reconhecida - o da complementaridade sexual - e uma ausência de parcela. "Operário", ou melhor "proletário", é da mesma forma o sujeito que mede a distância entre a parcela do trabalho como função social e a ausência de parcela daqueles que o executam na definição do comum da comunidade. Toda subjetivação política é a manifestação de um afastamento desse tipo. A bem conhecida lógica policial que julga que os proletários militantes não são trabalhadores mas desclassificados, e que as militantes dos direitos das mulheres são criaturas estranhas a seu sexo tem, afinal de contas, fundamento". (RANCIÈRE, 1996, p. 48).

${ }^{11}$ Caso em que a aura é mais explicitamente buscada como modo de diferenciação é o dos meninos que se pintam de prata com glitter comprado por quilo na 25 de Março para pedir dinheiro nas ruas. A afirmação "nóis é prateado" visa afastar a ideia de que são mendigos ou viciados em crack. (MANIR, 2015). Um tipo de aura na segregação. 12 Ainda segundo Sérgio Buarque de Holanda, "A democracia no Brasil foi sempre um lamentável mal-entendido. Uma aristocracia rural e semifeudal importou-a e tratou de acomodá-la, onde fosse possível, aos seus direitos ou privilégios, os mesmos privilégios que tinham sido, no Velho Mundo, o alvo da luta da burguesia contra os aristocratas. E assim puderam incorporar à situação tradicional, ao menos como fachada ou decoração externa, alguns lemas que pareciam os mais acertados para a época e eram exaltados nos livros e discursos" (HOLANDA, [1935], 1995, p. 160).

13 "É preciso observar que, diante da interpelação do indivíduo em sujeito pela ideologia, não há como resistir pois resistir é não constituir-se em sujeito. Porém, quando se trata dos modos de individuação do sujeito pelo Estado, há possibilidade de rupturas e, na falha da ideologia, o sujeito individuado pode resistir aos modos de individuação e romper com seus processos de identificação. É assim que entendemos a resistência." (ORLANDI, 2010, p. 15) 
${ }^{14}$ Em nota de rodapé, Orlandi ([2015] 2017, p. 145) comenta declaração do então prefeito de São Paulo, Fernando Haddad, sobre seu veto a uma lei de proibição dos bailes na periferia. Haddad defendera seu veto dizendo ser o funk uma "expressão legítima da cultura urbana jovem”. Orlandi nota que se fala de uma formação discursiva do campo da cultura diferente daquela do que a sociedade demanda enquanto movimento. Lembramos que, naquele momento, testemunhamos que, inclusive, no interior da militância petista, o veto de Haddad foi duramente criticado com a justificativa de que "só quem mora na periferia sabe a barulheira que é um baile assim", lembrança das contradições mal metaforizadas do consenso daqueles anos.

15 Sobre Drummond, Candido diz que "atinge então uma coisa bastante rara na poesia contemporânea: a expressão política sem qualquer aspecto de programa, como se fosse manifestação da mais profunda necessidade pessoal" (CANDIDO, 1999, p. 80).

16 "Nove pessoas morrem pisoteadas em tumulto após ação da Polícia Militar durante baile funk em Paraisópolis, em SP”. Disponível em: https://g1.globo.com/sp/saopaulo/noticia/2019/12/01/perseguicao-e-tiroteio-em-baile-funk-em-paraisopolisdeixa-ao-menos-8-mortos-pisoteados-em-sp.ghtml Acesso em: 02 jun.2021.

17 No documentário "Solta do Ponto" (2014), produzido pela GloboNews, sobre o "passinho do Romano", em bairro da zona leste de São Paulo, um dos garotos entrevistados diz que quer continuar a ser do funk quando crescer e, "se tudo der errado", como plano B, ser arquiteto. 